\title{
READY TO GO? EU ENLARGEMENT AND MIGRATION POTENTIAL: LESSONS FOR THE CZECH REPUBLIC IN THE CONTEXT OF IRISH MIGRATION EXPERIENCE. ${ }^{1}$
}

\author{
Wadim STRIELKOWSKI, * Cathal O’DONOGHUE**
}

\begin{abstract}
:
EU enlargement is hardly to be seen as the major push factor for migration. There are mainly economic factors that influence the migration decisions. Besides it seems that there is a migration potential, unique for every country, that pre-determines the migration or labour mobility. In our paper we (i) analyze the impact of internal economic factors, such as GDP growth, unemployment and wages on the emigration rate and (ii) compare the migration potential for the country distinguished by the high ratio of outward migrations (represented by Ireland) with those of the post-communist economy as well as the "new" EU member (represented by the Czech Republic). We come to conclusions that economic factors have the decisive role on pre-determining the migrations and that migration potential and the propensity to migrate as a reaction to worsening of the economic conditions at home are highly correlated. These can explain why there was no mass emigration from the EU "new" Member States to the "old" Member States after the recent enlargement, as far as it comes to migration potential needed for inducing such labour moves. The potential emigrants from new EU Member States are simply not ready to go to wealthier Member States in search of better wage and employment opportunities.
\end{abstract}

Keywords: migration, labour mobility, EU enlargement, Czech Republic, Ireland

JEL Classification: F02, F22, J61

\section{Introduction}

Among the most frequently named catalyzers of migration from a poor country or region to the wealthier one are wage differentials, economic disparities between regions, differences in GDP per capita and unemployment differentials. The works

*) National University of Ireland, Galway, University rd. Galway, Republic of Ireland (e-mail: strielkowski@ centrum.cz).

${ }^{\star *}$ ) National University of Ireland, Galway, IZA Bonn, University rd. Galway, Republic of Ireland (e-mail: cathal.odonoghue@ nuigalway.ie).

1) We are grateful to the Irish Social Science Data Archive for providing data.This paper has been financed under the IDARI project of the European Commission Fifth Framework Programme, Quality of Life and the Management of Living Resources, Key Action 5. 
of Hannan (1970), Todaro (1969), Harris and Todaro (1970) and Walsh (1984) usually focus on factors that are solely economic in their nature. Few of the migration theories look at the EU accession, other than the institutional changes that allow for easier work permissions, as the major factor of inducing migration moves. This is why it was surprising to see the discussions around the transitional period introduced for the labour force from the EU "new"2) Member States after the EU enlargement in May 2004.

While the majority of experts estimated migration flows from the EU "new" Member States as rather modest ones, this view has not been accepted by the policymakers and public opinion in the "old" EU Member States. The EU enlargement was consciously and unconsciously tied up to the triggering off the mass inflow of workers from the "new" countries") (Bauer, Zimmermann, 1999, and Boeri, Bruecker, 2000).

The recent experience shows that three EU "old" countries - Ireland, Sweden and the United Kingdom - which did not follow other EU Members and opened their labour markets to the newcomers do not experience any adverse effects associated with mass migrations or over-flooding of their labour markets with cheap labour.

The freedom of movement (of persons) is, alongside with the freedom of movement of capital, goods and services, one of the basic rights determining European Union. In theory, the creation of a Single Market presupposes the creation of many additional employment and earnings opportunities for the workers in various Member States of the EU. In addition, unrestricted labour flows should substantially reduce regional differences in economic opportunities within the EU.

The basic focus of this paper is to advocate the idea that the driving factors of migration and labour mobility are economic, not the EU accession. Besides we will try to prove that the scope and size of migrations strongly depend on the migration potential of population of a given country. For the population of countries with high migration potential it is more likely to react to the problems at home by increased emigration to the countries with higher income and lower unemployment (Fidrmuc, 2002). Some countries, however, do not posses that migration potential and thus might not react to wage and unemployment incentives abroad. This might be the case of the EU "new" Member States represented by the CEECs.

We will test these hypotheses based on the experience of two countries - Ireland, as a representative of the classical emigration country in the 1970s and 1980s, but belonging to the "old" EU; and the Czech Republic, which is a newcomer and a country which has got rid of the heritage of communist regime and socialist economy relatively recently.

\section{Methodology \& Literature Review}

The reasons leading to migration and the decision to move are reached through an evaluation of the incentives and obstacles to migration. Here push (unbearable or threatening conditions in the home country) and pull factors (incentives in the countries of immigration) play an important role (see for example Ravenstein 1876, 1885, 1889; or Dorigo, Tobler, 1983). Incentives may contain increased employment

2) Many authors use terms "core" EU countries and "new" EU countries referring to the EU Members before and after the enlargement on the $1^{\text {st }}$ of May 2004. We will call them "old" and "new" respectively for the sake of simplicity.

3) In this context those countries are mainly represented by the Central and Eastern European countries and the Baltic States which have joined the EU on the $1^{\text {st }}$ of May 2004. 
opportunities, better housing, or a more friendly political or cultural environment. Obstacles to migration are unfamiliarity with the new location, lack of information about distant opportunities, language barriers, transportations costs or difficulties and immigration or emigration restrictions. The pattern of migration is more or less the same everywhere: people leave poorer states in search of higher-paying jobs in richer states. The same patterns hold true within the European Union.

The research literature on migration suggests that a very complex set of interrelationships exists between social, psychological, structural and educational factors, as well as certain constraints on individual's migration decisions.

Individual's motives or reason for migrating require explanation. As De Jong (1983) suggests they are mainly explainable in terms of individual's locations in the economic and social structure, and level of educational background: because everything to what the individuals are aspiring to is given and predetermined by their educational level and social-economic or socio-cultural characteristics. However, people's beliefs or perceptions about how satisfactory local or foreign communities may be dependent also on the nature of the local economy or labour market (mainly on such factors as the rurality of the community and its unemployment (evel). So a direct linkage exists between the nature of the home community's economic structure and satisfying one's economic aspirations locally. For its rather short history of its existence, the EU has experienced five enlargements already. The story with each enlargement was different, and only four of them, including the recent enlargement, can encounter as those having an impact on the international migration and the issue of inter-EU free movement of labour.

EU membership, as it appears, by no means necessarily induces uncontrolled immigration to the core EU Member States. On the contrary, in the aftermath of their EU accession net emigration from Greece, Spain and Portugal in the first half of the 1980s has substantially declined. In spite of that, recent EU Eastern enlargement, encountering mostly post-communist countries of the Eastern and Central Europe aroused many doubts to what will be the effect of introducing the free movement to labour onto the countries with their GDP per capita hardly reaching the "old" EU average. There are various reports and papers on that issue (see Bauer, Zimmermann, 1999; Boeri, Bruecker, 2000 and Zimmermann, 2004) assessing the post-enlargement migration, however, none of them contains a catastrophic scenario. Even now, more than half a year after the enlargement, the issue remains open (and the free mobility of labour chapter closed) so to speak - all this in spite of the fact that there has never been registered a mass migration basing on the data from those EU countries who opened their labour markets to the workers from the "new" Member States, namely Ireland, Sweden and the U.K.

There are some methodological issues to be discussed here in connection with what has been said previously. Firstly, even though the migration from the "new" Member States to the "old" EU countries might be generally caused by the economic incentives, it does not necessarily hold true that the "response rationale" will be the same as in the case of traditionally emigration countries, such as Ireland or Portugal. Secondly, it might be relevant to measure the migration potential of the population in the "new" Member States. Various reports (see for example Fidrmuc, 2002) suggest that the labour mobility in the "new" Member States has been low and falling, this happening even in spite of increasing wages and unemployment disparities across regions. In fact, it seems that only the prosperous regions are dealing with migration, moreover this migration covers high-skilled workers. If this is true, then the EU accession will have the adverse effect on the "new" Members. 


\section{1 Migration Patterns and Economic Shocks: the Case of Ireland}

The topic of emigration, including the migration of labour, has been of considerable importance for Ireland since the early part of the last century. For much of the last century emigration has remained high and the population decline continued until 1961. But even in the 1960s, emigration continued and after a decade of unprecedented inflows in the 1970s, net outflows resumed in the 1980s. Part of the reason for the deeply-felt Irish sensitivity to the emigration problem (and the reason why it becomes a focus of social, economic and political debate) stems from its long-standing historical nature. While the populations of most European countries have substantially increased since the middle of the $19^{\text {th }}$ century, Ireland, on the other hand, has been unique in recording a population decline for the most of the period. Most of the more or less industrialised northern countries were net importers of people during the economically prosperous 1960s. This period is represented by the era of the "guest worker", as millions migrated from the countries of Mediterranean basin to find employment in the industrial centres of Germany, France and other northern European countries.

This pattern continued into the early 1970s but the scene changed in middle of that decade when economic conditions deteriorated following the first oil price shock in the late 1973. Not surprisingly, migrant workers, who were generally unskilled and held less secure jobs in the economies concerned, suffered disproportionately through unemployment in the following economic fallout. Many returned to their home countries; indeed, in some countries those workers, who originated from outside the EU were forced to do so by various means.

Ireland also experienced a reversal of its long-standing migration pattern during the 1970s, but the underlying reasons were different from those indicated above for the other EC countries. Most of the influx derived from improvement in employment opportunities and enhanced social conditions at home, rather than from a desire to escape from the recession abroad. Indeed, even though the effects of the mid decade recession in Ireland were as great as they were in other countries, the net inflow of population continued throughout its duration.

Emigration, when viewed in a wider European context over the post-war period, is not a feature which is unique to Ireland. One must, therefore, when considering the wider context of a deregulated EU labour market, exploit the possibility of continuing intra-European movements, with a likely gravitation towards these centres where economic growth will tend to be concentrated. Differences in demographic structure between the EU countries are also likely to contribute to such movements.

\subsubsection{Waves of Irish Migration}

In the decades since political independence of the Republic of Ireland there has been a substantial and almost never-ceasing net outflow of emigrants. The NESC report of 1991 states that this peaked in the decade $1951-1961$. After the decline in the net outflow $(1961$ - 1971) and the subsequent net inflow $(1971-1981)$, the net outflow figure has risen again rapidly since 1981 (NESC, 1991). This process has, however, been stopped in the beginning of the 1990s and for the last decade of the $20^{\text {th }}$ century Ireland has been the net importer of the labour force.

Some authors (Mac Laughlin, 1994 and Hazelkorn, 1990) show that for the most part of the $20^{\text {th }}$ century Ireland remained highly-dependent upon Britain both as a market for its exports and as a host of its "surplus" labour. The population shifts from Ireland to the U.K. were merely a part of a broader general process of urban-rural drift. 
The situation of the World War II when the neutral Ireland was an automatic supplement of labour for Britain continued to play its role in the 1950s and 1960s. Labour emigration in this context was clearly caused by the Ireland's geographical proximity to Britain. The location of Ireland caused its position of an emigrant nursery for the U.K. as well contributed to the process of peripheralisation in Ireland (Coulter, 1994).

While the improving conditions at home made many Irish migrants to return back, the beginning of the 1980s was again marked by the high numbers of net outflows. As Mac Laughlin (1994) points out since 1980s, emigration has been particularly affecting Irish teenagers and represented a mixture of urban-rural migration. Results from most recent surveys show that this "new wave" emigration is still largely a survival strategy for working-class and small-farming families and primarily affects middle-class families. Furthermore, the traditional view of an Irish migrant looked upon as an unskilled rudimentary worker should be revised - more and more emigrants posses second- and third-level qualifications (NESC, 1991). The EC accession seemed to have no substantial influence on the Irish labour migration - in fact the period of 1971 - 1981 was marked by the decrease in emigration outflow. Britain and the English-speaking countries absorbed the largest part of Irish excessive labour flows (see Farrell, 1991).

It is easy to understand why the rate of emigration from Ireland has been so high over the past two centuries. Few other countries face the combination of circumstances that have led to such a high long-term rate of emigration from Ireland: a high birth rate and the pressure on the labour force, low average income levels and a long-term rate of economic growth that has not been sufficient to close the gap in living standards relative to the other EU Members, the widespread use of English and free access to Britain.

\subsection{Migration Potential of the Czech Republic}

Unlike Ireland presented in the previous case, the Czech Republic is a country with low labour mobility. This concerns both inter-regional migrations and outward international migrations. Similarly to Ireland with the UK as the market for its "surplus" labour, the Czech Republic has had Germany and Austria with only one difference: political and economic barriers did not turn these migrations into the largescale flows. Legal employment of the Czech citizens after the collapse of the Iron Curtain was processed in several forms: seasonal works (up to three months in a year), employment on the basis of agreements, bilateral employments with educational purposes and the so-called "pendling" (VUPSV, 2001). "Pendling" or simply working in one country without residing there (a worker usually returns home every night and spends most of his earnings in the home country) existed on a large-scale in the first half of the 1990s (12,000 workers annually), however, by the end of the decade the number of Czech pendlers has decreased by 60 per cent (VUPSV). One of the reasons for that was, on the one had, the decrease in issuing of working permits for Germany and Austria and on the other hand the loss of interest in low-paid and low-qualified jobs. According to Austrian statistics, prior to the EU enlargement (and thus gaining some special privileges for the Czech workers) employees from the Czech Republic were merely 10 per cent of the largest group of employees from the former Yugoslavia and yielded 10.8 thousand people in the 2002 (Austrian labour statistics, 2003). The second-largest group were the Turks and later followed by Hungary and Poland. The same situation could have been observed in Germany: in the 2002 Czech employees constituted 4 per cent (13.2 thousand persons) of the largest group of foreign employees from Turkey (German labour statistics, 2003). 
This comparisons show that under the equal treatment and labour law, only a small fragment of the Czech labour force was seeking employment abroad, even though the geographical proximity of the Czech Republic is considerably higher than in the case of Turkey or Yugoslavia.

One more important fact that we mentioned when describing Irish migration, was the knowledge of language. One of the most crucial predeterminants of the Irish migration is the fact that the Irish speak English and thus can easily take up employment in the U.K. or the USA. With the incerasing popularity of English as lingua franca more and more young people from the Czech Republic are likely to look for employent opportuntities in the English-speaking countries, which can also be used as an explanation of loosing interest in Austria and Germany. It can be stated that like any other post-communist country (perhaps with the exception of Poland) the Czech Republic has very low regional migration turnover in comparison with the "old" EU Member States.

The reasons to the low regional mobility are mostly the housing market and the cultural specifics (mostly granted employment in the communist times and thus tightness to the place of work and residence). Some authors (for example Vavrejnová, 2004) suggest that up to now the decisive factor of the low regional migrations has been badly-functioning housing market. Privatization of state-owned apartments, especially selling apartments in the regions with high unemployment has contributed to "chaining" local labour force in these regions and helping to spreading the speculations with those apartments (this, in its turn, lead to decreasing of available housing stock for the social cases). In spite of privatization, private apartments still constitute just 46 per cent of the housing stock in the Czech Republic (Czech Statistical Office, 2004).

An interesting fact is that change of the workplace and moving closer to the workplace are the most irrelevant factors of the regional migrations according to the Czech Statistical Office. In 1999, when the unemployment rate in the Czech Republic was about 8.5 per cent, these two reasons made 6 per cent of the total regional migration turnover and remained on the same scale even when migration had risen to 10 per cent in 2002 (Czech Statistical Office, 2004).

\section{D a t a}

We have elaborated a comparative study of two countries: Ireland and the Czech Republic in order to demonstrate the dependence of migration flow on the economic factors and analyze the migration potential. We analyze inward, outward and net (immigration minus emigration) migrations in both countries. Another part of the analysis covers the migration potential measured by the number of migrants from and to the administrative regions of the two selected countries as a reaction to the economic incentives, such as expected income and employment rate within each state. To our mind Ireland is distinguished by the high migration potential and Irish labour force reacts quickly to the economic changes at home and incentives elsewhere. Irish population has been marked by a high rate of emigration throughout the last century subject to the worsening conditions at home.

The Czech Republic, on the other hand, is a typical example of the post-communist country, which has undergone the change from zero unemployment to the problems of the capitalist economies. Some evidence let us suspect that the migration potential here is low and thus nothing can verify alleged mass migrations to the West. This is given by local specifics and, to the great extent, by the heritage of the communist economy. The data are covering the periods of several years and the scope of data differs somehow. To make the data, and thus the analysis of both 
countries, comparable we had to adjust the data from Irish Central Statistical Office to those from the Czech Statistical Office. The problem with the data was mainly the fact that Irish migration and economic data are gathered in whole-national censuses taking place every 5 years. We have focused on the Censuses of 1981, 1986, 1991, 1996 and 2002 and used data on emigration, immigration (both without distinguishing the regions of origin or destination of migrants), disposable income ${ }^{4}$ and employment by micro-regions (County or DD1 level) in Ireland to generate the yearby-year values. While no emigration data is explicitly collected in the Irish Census, it has been possible to impute estimates of emigration flows. Utilising information on population change, deaths and births at the county level, we were able to impute the number of net migrants between census points (generally 5 years). This together with information on the number of immigrants in the previous year allows us, using interpolation methods to calculate the number of emigrants.

We have also performed an exercise of clearing our data on Ireland of the people aged 65 and over (as those not being relevant for inter-regional migrations as far as many pensioners are retiring and returning back to Ireland from Scotland and USA).

The data for the Czech Republic cover the period of $1995-2001$ and represent the observations of disposable income (average monthly salary) by regions and employment structure according to main sectors of economy. We have also included GDP per capita for each region and perform the analysis with and without it.

Most of the data has been obtained from the Eurostat, the Irish Statistical Office and the Czech Statistical Office. The regional data from the Czech Republic and Ireland are divided by regions ('kraje' in Czech, 14 regions in whole) in the Czech Republic and counties (34 counties) in Ireland. The data report overall immigration and emigration per region, without distinguishing the regions of origin or destination of migrants. The fact that the data report migration of populations rather than labour migration may cause problems when interpreting the results, but this is a problem of all migration studies and is subjected to the availability of the data. The comparative study will show the patterns for both countries: one with high migration potential and the other with the low one and will help us to draw the results and conclusions for the inter-EU migrations.

\section{Empirical Model}

In this section of our paper we will draw an econometric model estimating the dependence of migration on economic factors and migration potential of the population.

When it comes to estimating the interdependence between the migration and various economic factors, the usual procedure adopted in migration studies (see for example Walsh, 1974) is to relate the annual rate of net migration, $M$ (net emigration is treated as negative migration) with wage ratio of emigration and immigration country (Wemig/Wimm) and unemployment rate ratio (Uemig/Uimm). The aim of such studies is to try to explain the year-to-year fluctuations in the level of migration. It is valuable to combine the findings of these studies with those of studies of the factors that increase the likelihood that individuals will emigrate. Most of the migration studies depict evidence that these variables affect migration in the expec-

4) We utilise time invariant disposable income as our regressor as the time series of the county level disposable income is not sufficiently long. However, as there is a high level of temporal correlation, this is not a major issue. 
ted manner. This seems to be consistent with the hypothesis that fluctuations in the rate of emigration reflect changes in labour market conditions (wage levels and employment opportunities) in country of emigration relative those to the country of immigration. In spite of that, a number of unresolved issues arise from the econometric evidence. The problem is, of course in the data sources. While the data on aggregate net flows are available the allocation of this total among individual years could be subject to error. Besides, the annual net migration data relate to the whole population and not just those in the labour force or of working age. These limitations reduce the reliability of econometric models (see Keenan, 1981).

In their study Geary and O'Gráda (1989) estimated a migration model of Irish migrations to the UK for the period of 1953 - 1982. They advocate the use of expected income $(Y)$ and relative expected income (RELY- ratio of expected income in Britain to that in Ireland) as key determinants of migration, where $Y$ is defined as follows: $Y=u B+(1-u) W(1-t)$, where $u=$ unemployment rate (as a proportion), $\mathrm{B}=$ the level of social welfare payments to the unemployed, $W=$ gross wages and $t$ = income tax rate (including social security contributions).

Expected income is therefore a weighted average of the income received by the employed and unemployed labour force, using the proportions of the labour force unemployed and employed as weights. RELY variable combines the influence of both relative unemployment rates and relative wages in a single variable.

Geary and O'Gráda report the following results for the Irish migrations for the period of 1953 - 1982:

$$
M=67.88-.758^{\star} R E L Y+.195^{\star} M-1, R^{2}=0.852,
$$

where $M=$ net Irish migration of $15-64$ year olds expressed in thousands and RELY = Yirl/Yuk expressed as an index to base 1980 = 100 (see Geary, O'Gráda, 1989).

The result shows that the higher is expected income in Britain relative to the Republic of Ireland, the higher the rate of emigration.

\subsection{Dependence of International (Outward) Migrations on Economic In- centives at Home}

Referring to the study of Geary and O'Gráda we will attempt to construct similar model in order to estimate the impact of economic factors in the emigration country on the outward migration:

$$
M_{i}=\beta_{0}+\beta_{1} Y+\beta_{2} W+\beta_{3} U+\beta_{4} P O P U L+u_{i}, \quad i=1,2, \ldots n
$$

where $M$ is the outward migration from the country, $Y$ is GDP per capita, $W$ is the average wage in the country, $U$ is the unemployment rate in the country and $P O$ $P U L$ is the population of the country in each year. Unlike the previous studies quoted, because of the multitude of potential destinations of migration, we will not estimate the dependence of emigration on the difference in economic factors of the country of origin and countries of immigration, but rather focus on the push factors (worsening the economic conditions at home) as an explanatory variable of emigration. The core of this approach is the fact that we are focusing on the migration potential of the population and therefore the first step will be to access the reaction of the population to the internal shocks: for this purpose we run the same regression for the Czech Republic and Ireland.

The following table represents the results of the regression for the net outward migration from the Czech Republic for the years of $1991-2002$. An interesting fact is the behaviour of GDP per capita variable. It seems that it has a negative influen- 
ce on the net migration, thus an increase in GDP would lead to reducing the net migration and therefore to the increase of the emigration (as far as net migration is, by definition, the difference between immigration and emigration).

Table 1

Determinants of Out Migration: Czech Republic (1991-2002), Net Migration (NM)

\begin{tabular}{|l|c|c|c|c|c|r|}
\hline & Coef. & Std. error & $T$ & $P>|t|$ & \multicolumn{2}{|c|}{ [95\% Conf. Interval] } \\
\hline GDP per capita & -.0002767 & .0001283 & -2.16 & 0.063 & -.0005726 & .0000191 \\
\hline Nominal wage & .0049727 & .0020104 & 2.47 & 0.038 & .0003367 & .0096086 \\
\hline Unemployment & -.0082188 & .0075461 & -1.09 & 0.308 & -.0256202 & .0091825 \\
\hline Population & .0628302 & .020089 & 3.13 & 0.014 & .0165047 & .1091556 \\
\hline Constant & -649.224 & 207.3225 & -3.13 & 0.014 & -1127.31 & -171.1375 \\
\hline R-squared & \multicolumn{7}{|c|}{0.6898} \\
\hline Adj R-squared & \multicolumn{7}{|c|}{13} \\
\hline $\mathrm{N}=$ & \multicolumn{7}{|c|}{0.5347} \\
\hline
\end{tabular}

The results can be also reported in the following way:

$$
M_{i}=-649.224-.0002 Y+.0049 W-.0082 U+.0628 P O P U L+u_{i}
$$

The other variables have the signs as expected: the increase in both the nominal wage and unemployment would lead to the increase in net migration and decrease, respectively. The population variable is used for testing the relationship between the size of population and net migration, the relationship is positive and thus. One substantial thing we would like to draw attention to are the small values of the coefficients. Although the $R$-squared (and adjusted $R$-squared) seem very good, the in-

Table 2

Determinants of Out Migration: Ireland (1980-2002), Net Migration (NM)

\begin{tabular}{|l|r|r|r|r|r|r|}
\hline & \multicolumn{1}{|c|}{ Coef. } & \multicolumn{1}{c|}{ Std. error } & \multicolumn{1}{c|}{$T$} & \multicolumn{1}{c|}{$\mathrm{P}>|\mathrm{t}|$} & \multicolumn{2}{|c|}{ [95\% Conf. Interval] } \\
\hline GDP per capita & .0000364 & .000719 & 0.05 & 0.962 & -.0014759 & .0015451 \\
\hline Nominal wage & -.0007804 & .0027722 & -0.28 & 0.782 & -.0066046 & .0050438 \\
\hline Unemployment & -1.527573 & .864728 & -1.77 & 0.094 & -3.3443 & .2891549 \\
\hline Population & .0329989 & .0689401 & 0.48 & 0.638 & -.1118498 & .1778286 \\
\hline Constant & -94.04865 & 228.4288 & -0.48 & 0.685 & -573.9598 & 385.8625 \\
\hline R-squared & \multicolumn{7}{|c|}{0.3701} \\
\hline Adj R-squared & \multicolumn{7}{|c|}{2302} \\
\hline $\mathrm{N}=$ & \multicolumn{7}{|c|}{23} \\
\hline
\end{tabular}


significant coefficient on the unemployment variable in the model suggests that emigrants from the Czech Republic do not consider the unemployment in the country when making their migration decisions. There is also some evidence of multicollinearity in the GDP and wage variables.

Now, let us do the same exercise for the Irish emigration. This time we will use more extensive database going back to the 1980 in order to see the development of the Irish migration rate over time and in the periods of extensive outward migrations. The data includes periods of large scale emigration in the late 1980s and immigration in the late 1990s.

The results can be also reported in the following way:

$$
M_{i}=-94.048-.00003 Y-.0007 W-1.527 U+.03299 P O P U L+u_{i}
$$

If we compare both results, we can clearly see the difference. While the signs on the coefficients are similar, the significance of the estimates are opposite with unemployment being the main most decisive "push" factors for the Irish migrants. Comparing the push factor mode with the Geary and O'Grada the model highlights the important role pull factors play, indicating the fact that the UK and Irish labour markets operate similar to a regional market rather than international labour markets. It also highlights that for much of the period in question, unemployment and wealth followed a different pattern, with high unemployment levels continuing, except for the end of the period, even during periods of higher growth. Thus differential labour demand between Ireland and the UK was an important driver. We can clearly see that in spite of methodological differences, the outward migrations from Ireland were dependent on the internal economic factors to the less extent that those in the case of the Czech Republic due to the importance of the pull factors experienced by Ireland from the UK.

\subsection{Dependence of Regional Migrations on Economic Incentives at Home}

According to Fidrmuc (2002) migration can be one of the principal mechanisms for absorbing asymmetric shocks. A region hit by, say, negative demand shock will face increasing unemployment and decreasing wages. There are several ways to absorb this shock: for instance, residents of the regions can move to the region with higher wages and lower unemployment; or lower wages can attract potential investors. In this part of our model we will compare the emigration potentials of Ireland and the Czech Republic by measuring the responsiveness of regional flows to respective regional economic characteristics. The dependent variables are gross and net migration flows. The data record the total number of migrants arriving to or leaving the region in a given year without any special regard to their destination.

We assume that in order for the country's population to have strong migration potential, net immigration should be positively related to average wages and negatively to unemployment, while gross emigration should be positively related to unemployment and negatively to wages. The vice versa situation suggests the existence of immobile population which does not react to asymmetric shocks.

The formal model can be presented in the following way:

$$
N M_{h}=\beta_{0}+\beta_{1} D I S P_{-} Y_{h}+\beta_{2} E M P R A T E \_Y_{h}+u_{i} \quad i=1,2, \ldots n
$$

Where $N M$ is the gross and net migration flow (total numbers of migrants arriving/leaving a district in a given time period without identifying the destination) normalized by population and the dependent variables: EMPRATE_ $Y_{h}$ and DISP_ $Y_{h}$ represent regional economic characteristics, such as employment rate and dispos- 
able income per capita in the region. We expect both employment and disposable income to have a disproportional relationship with respect to emigration. In order for migration to be effective as a channel of regional adjustment, gross (and net) immigration should be positively related to both disposable income and employment, while emigration should be negatively related to employment and wages.

The following table summarizes the determinants of regional migrations for the Republic of Ireland5):

Table 3

Determinants of Regional Migration: Ireland (1986-2002)

\begin{tabular}{|l|cc|cc|cc|}
\hline & Immigration & Std. errors & Emigration & Std. errors & Net migration Std. errors \\
\hline Disposable income & $-3.21 \mathrm{e}-06$ & $(.0000998)$ & $6.00 \mathrm{e}-06$ & $(.0001228)$ & -.0002455 & $(.0002856)$ \\
\hline Employment rate & .1001516 & $(.0204264)$ & .1546487 & $(.0251237)$ & .1739801 & $(.0584371)$ \\
\hline Constant & -.0318659 & $(.0109108)$ & -.0609712 & $(.0134199)$ & -.0665878 & $(.0312143)$ \\
\hline R-squared & \multicolumn{2}{|c|}{0.1695} & 0.2453 & 0.0627 \\
\hline Adj R-squared & \multicolumn{2}{|c|}{0.1571} & \multicolumn{3}{|c|}{0.2339} & \multicolumn{2}{c|}{0.0486} \\
\hline$N=$ & \multicolumn{3}{|c|}{136} \\
\hline
\end{tabular}

Note: dependent variable - migration rate

We see that the Irish population, as expected, is highly mobile and reacting to the changes in economic incentives within region. In each case, we see that county income differentials are less important than employment differentials, which are

Table 4

Determinants of Regional Migration: the Czech Republic (1995-2000)

\begin{tabular}{|c|c|c|c|c|c|c|}
\hline & Immigration & Std. errors & Emigration & Std. errors & \multicolumn{2}{|c|}{ Net migration Std. errors } \\
\hline $\begin{array}{l}\text { Disposable income } \\
\text { Employment rate } \\
\text { (I) }\end{array}$ & $\begin{array}{r}-0.0535 \\
3105.852\end{array}$ & $\begin{array}{r}(0.1637) \\
(3333.041)\end{array}$ & $\begin{array}{r}-0.9956 \\
1657.357\end{array}$ & $\begin{array}{r}(0.11995) \\
(2440.987)\end{array}$ & $\begin{array}{l}-0.08906 \\
1860.283\end{array}$ & $\begin{array}{r}(0.09856) \\
(2005.752)\end{array}$ \\
\hline $\begin{array}{l}\text { Employment rate } \\
\text { (II) }\end{array}$ & 2962.914 & (3338.63) & 1445.223 & (2445.08) & 1823.915 & (2009.115) \\
\hline $\begin{array}{l}\text { Employment rate } \\
\text { (III) } \\
\text { Constant }\end{array}$ & $\begin{array}{r}3290.936 \\
-308418.7\end{array}$ & $\begin{array}{r}(3348.273) \\
(333980)\end{array}$ & $\begin{array}{r}1814.475 \\
-159736.5\end{array}$ & $\begin{array}{l}(2452.143) \\
(244593.7)\end{array}$ & $\begin{array}{r}1837.757 \\
-181544.7\end{array}$ & $\begin{array}{r}(2014.919) \\
(200982)\end{array}$ \\
\hline$R$-squared & \multicolumn{2}{|c|}{0.455} & \multicolumn{2}{|c|}{0.644} & \multicolumn{2}{|c|}{0.035} \\
\hline Adj $R$-squared & \multicolumn{2}{|c|}{0.427} & \multicolumn{2}{|c|}{0.626} & \multicolumn{2}{|c|}{-0.013} \\
\hline$N=$ & \multicolumn{6}{|c|}{84} \\
\hline
\end{tabular}

5) We report poolled regression model as county effects were found not to be significant in a panel data model. 
Table 5

\section{A Number of Studies on Migration from the CEE Countries to the EU}

\begin{tabular}{|c|c|c|c|}
\hline Authors/Year & Predicted value & Countries included & Methods/remarks \\
\hline Layard et al. 1992 & $\begin{array}{l}130 \text { thousand immigrants per } \\
\text { year in western countries }\end{array}$ & $\begin{array}{l}\text { Estimates for Poland, } \\
\text { Czechoslovakia and Hungary } \\
\text { (projected on the other CEE } \\
\text { countries) }\end{array}$ & $\begin{array}{l}\text { Method of potential estimation of } \\
\text { South-North migration flows ( } 3 \% \\
\text { of population in } 1950-1970 \text { ) }\end{array}$ \\
\hline $\begin{array}{l}\text { Brueker/Franzmeyer } \\
1997\end{array}$ & $\begin{array}{l}\text { Depending on the scenario: } \\
\text { (1) } 340 \text { - } 680 \text { thousand per year } \\
\text { in the EU } \\
\text { (2) } 590 \text { thousand }-1 \text { million } \\
800 \text { thousand per year in EU }\end{array}$ & $\begin{array}{l}\text { (1) Five countries: Poland, } \\
\text { Hungary, Czech Republic, } \\
\text { Slovakia and Slovenia } \\
\text { (2) All candidate countries }\end{array}$ & $\begin{array}{l}\text { Gravitational model (embodying } \\
\text { different economic parameters, } \\
\text { the importance is given to wage } \\
\text { differentials). }\end{array}$ \\
\hline $\begin{array}{l}\text { Fassmann/Hinter- } \\
\text { mann } 1997\end{array}$ & $\begin{array}{l}721 \text { thousand - actual migration } \\
\text { potential, } 320 \text { thousand to } \\
\text { Germany, } 150 \text { thousand to } \\
\text { Austria }\end{array}$ & $\begin{array}{l}\text { Czech Republic, Poland, } \\
\text { Slovakia and Hungary }\end{array}$ & $\begin{array}{l}\text { Representational research of } \\
\text { Gallup Institute in all four } \\
\text { countries included in the } \\
\text { prognoses }\end{array}$ \\
\hline Aintila 1998 & $\begin{array}{l}\text { About } 13 \text { thousand immigrants } \\
\text { to Finland each year }\end{array}$ & Baltic countries and Poland & Same as Layard 1992 \\
\hline $\begin{array}{l}\text { Birner/Huber/Winker } \\
1998\end{array}$ & $\begin{array}{l}\text { (1) } 24,100 \\
\text { (2) } 21,700 \text { Regional flows of } \\
\text { migrants in the year of accession } \\
\text { (to Austria). }\end{array}$ & $\begin{array}{l}\text { Czech Republic, Poland, } \\
\text { Slovakia, Slovenia and Hungary }\end{array}$ & $\begin{array}{l}\text { (1) The year of accession is } \\
\text { settled on } 2004 \text {. } \\
\text { (2) The year of accession is } \\
\text { settled on 2010. Methods taken } \\
\text { from Walters-kirchen/Dietz for } \\
\text { Austrian border regions. }\end{array}$ \\
\hline Hofer 1998 & $25-40$ thousand per year & $\begin{array}{l}\text { Same as Brueker/Franzmeyer } \\
1997\end{array}$ & $\begin{array}{l}\text { Estimations of Brueker/ } \\
\text { Franzmeyer results }\end{array}$ \\
\hline $\begin{array}{l}\text { Lundborg et al. } 1997 \\
\text { Lundborg } 1998\end{array}$ & $\begin{array}{l}628 \text { thousand }-1 \text { million } \\
885 \text { thousand of workers (with } \\
\text { the families) to EU countries } \\
\text { in } 15 \text { years, } 126 \text { thousand, } \\
20-30 \text { thousand of workers to } \\
\text { Sweden alone. }\end{array}$ & Baltic countries and Poland & Same as Layard 1992 \\
\hline $\begin{array}{l}\text { Šujanová/Šujan 1997 } \\
\text { (later Huber-Pichel- } \\
\text { mann 1998, Hofer } \\
\text { 1998) }\end{array}$ & $\begin{array}{l}39 \text { thousand in } 2005-2010 \\
\text { to EU }\end{array}$ & Czech Republic & Econometric model \\
\hline $\begin{array}{l}\text { Huber/Pichelmann } \\
1998\end{array}$ & $140-200$ thousand to EU & CEECS & $\begin{array}{l}\text { Based on Šujanová/Šujan method } \\
\text { used for all countries }\end{array}$ \\
\hline $\begin{array}{l}\text { Šik } 1998 \text { (later } \\
\text { Huber 1999, Salt } \\
\text { 1999) }\end{array}$ & $\begin{array}{l}\text { Migration potential in the border } \\
\text { regions is irrelevant. }\end{array}$ & Hungary & Panel research \\
\hline $\begin{array}{l}\text { Walterskirchen/Dietz } \\
1998\end{array}$ & $\begin{array}{l}\text { (1) } 42 \text { thousand } \\
\text { (2) } 31,600 \text { to Austria (workers } \\
\text { and commuters), } 150-200 \text { each } \\
\text { year for five years (workers), } \\
150 \text { thousand for commuters in } \\
\text { the long run }\end{array}$ & $\begin{array}{l}\text { Czech Republic, Poland, } \\
\text { Slovakia, Slovenia, Hungary }\end{array}$ & $\begin{array}{l}\text { Same as Brueker/Franzmeyer } \\
\text { (1) if free movement is to be } \\
\text { implemented in } 2005 \text {. } \\
\text { (2) If it is to be implemented } \\
\text { starting from } 2015 .\end{array}$ \\
\hline
\end{tabular}


Table 5 (continuation)

\section{A Number of Studies on Migration from the CEE Countries to the EU}

\begin{tabular}{|c|c|c|c|}
\hline Authors/Year & Predicted value & Countries included & Methods/remarks \\
\hline Wallace/IOM 1998 & $\begin{array}{l}\text { No exact numbers, but the } \\
\text { explanation of migration and the } \\
\text { preferable countries (Germany) }\end{array}$ & $\begin{array}{l}\text { Poland, Czech Republic, Slovakia } \\
\text { and Slovenia, Hungary, Romania, } \\
\text { Bulgaria, Croatia, former } \\
\text { Yugoslavia, Ukraine and Belarus }\end{array}$ & $\begin{array}{l}\text { Representational research base } \\
\text { on questioning of about } 1,000 \\
\text { people in each country }\end{array}$ \\
\hline $\begin{array}{l}\text { Bauer/Zimmerman } \\
1999\end{array}$ & $\begin{array}{l}\text { About } 3 \text { million in the next } \\
10-15 \text { years, } 200 \text { thousand } \\
\text { each year to EU }\end{array}$ & $\begin{array}{l}\text { Bulgaria, Czech Republic, } \\
\text { Hungary, Poland, Romania, } \\
\text { Slovenia, Slovakia }\end{array}$ & $\begin{array}{l}\text { Same as Layard 1992. Two } \\
\text { scenarios: transition periods and } \\
\text { immediate free movement }\end{array}$ \\
\hline $\begin{array}{l}\text { Fertig } 1999 \\
\text { (Huber 1999) }\end{array}$ & $\begin{array}{l}\text { (1) } 38-31 \text { thousand each year } \\
\text { to Germany for the next } 20 \text { years, } \\
\text { (2) } 39-33 \text { thousand each year }\end{array}$ & $\begin{array}{l}\text { (1) first candidates: Czech } \\
\text { Republic, Estonia, Hungary } \\
\text { and Poland }\end{array}$ & $\begin{array}{l}\text { Hatton model (1995) used, } \\
\text { estimations based on statistics } \\
\text { of the Bureau of Migration in } \\
\text { Germany and with the } \\
\text { assumption of the economic } \\
\text { growth of } 2 \% \text { in CEECs. }\end{array}$ \\
\hline Salt et al. 1999 & 41 thousand each year to EU & $\begin{array}{l}\text { Czech Republic, Estonia, } \\
\text { Hungary, Poland and Slovenia }\end{array}$ & $\begin{array}{l}\text { Projection of the basic } \\
\text { immigration factors of chosen EU } \\
\text { countries (1985-1995) }\end{array}$ \\
\hline
\end{tabular}

Source: see references below.

highly significant, in driving migration. While this may be due to the fact that there is no inter-temporal variation in this variable (merely inter-county variation), it may indicate that individuals migrate more in search of work than in search of a higher standard of living.

Now let us compare the results we obtained for Ireland with those for the Czech Republic. The results show that the pattern that we can obtain for migration in the Czech Republic does not meet the criteria for migration being effective as a channel of regional adjustments. At the county level as the national level, the employment rate is not a significant driver of migration flows and only in the case of emigration disposable income is a strong driver. However, the sign has the opposite sign to what one would expect from an economic rationale, indicating that emigration is higher from richer regions. This may capture the fact that those in richer regions may be more likely to have skills such as language and educational qualifications and resources to facilitate migration, while those from poorer regions have characteristics and constraints so that they are less likely to migrate. The immigration is negatively related to disposable income in the case of the Czech Republic, not mentioning the determinations coefficient for net migrations and explaining factors. We have run the regressions for each sector of economy separately and it turns out that relationship is self-explaining only in the case of employment rate in primary sector (agriculture).

\section{Conclusions}

As we have seen, the main driving factors of migration, especially labour migration, are economic. Apart from that there is a migration potential of population that plays crucial role in the international migrations.

The specific focus should be on distinguishing the impact of economic differences between immigration and emigration country and economic processes in the 
country of emigration on the trends of international migration. Our analysis comparing the relationship of net migration, emigration and immigration with income and employment in the regions for the Czech Republic and Ireland shows that migration potential of population of different countries varies: regions with favourable economic conditions tend to experience high immigration as well as emigration, whereas depressed regions display generally low labour mobility. Our findings suggest that this variation will be in favour of countries with the more "mobile" population such as the Republic of Ireland. More "mobile" population measured in regional emigration and immigration responsiveness to the changing economic conditions at home might mean that economic incentives abroad as well as opening of new foreign labour markets due to the political decisions (such as the EU enlargement) will very likely lead to larger migration of labour searching for higher wages and employment opportunities. No doubt, there is a wide scale of factors, not just economic ones that can affect migrations: social and cultural factors (such as habits and language), housing possibilities and demographic characteristics and many more that can be considered in an analysis of this type. However, we wanted to show that the main motives are always economic.

In this context it can be argued that EU enlargement itself may not necessarily play a decisive role in triggering off the migrations from the "new" Member States. In order for this to happen, the emigrants should strongly react to the economic changes in the country and be highly mobile within their country. Without these two important factors the economic disparities going hand in hand with attractive employment opportunities, as those existing in the enlarged EU 25, may result in a such a large influx of migrants from the East. Accessing the migration potential in the CEECs we can see that it is quite low and thus it is unlikely that the recent trend of very modest migrations to the "core" EU is going to change.

References

Bauer, T., Zimmermann, K. F. (1994), "Modelling International Migration: Economic and Econometric Issues," in: van der Erf, R., Heering, L. eds., Causes of International Migration Proceedings of a workshop. Luxembourg, Office for Official Publications of the European Communities, pp. 95-115.

(1999), "Assessment of Possible Migration Pressure and its Labour Market Impact Following EU Enlargement to Central and Eastern Europe”. IZA, Bonn.

Boeri, T., Bruecker, H. (2000), "The Impact of Eastern Enlargement on Employment and Labour Markets in the EU Member States". Berlin and Milano, European Integration Consortium, DIW, CEPR, FIEF, IAS, IGIER.

Borjas, G. J. (1987), "Self-Selection and the Earnings of Immigrants." American Economic Review, 77 (4), 531-553.

ber), 1667-1717.

(1994), "The Economics of Immigration," Journal of Economic Literature, XXXII (Decem-

Coulter, C. (1994), "Ireland, between the First and the Third Worlds", Dublin: Attic Press.

De Jong, G., et al. (1983), "International and Internal Migration Decision-Making". International Migration Review, vol. 17 , No. 3.

et al. (1986), "Migration Intentions and Behavior. Decision-Making in a Rural Philippi-

nes Parish", in Fawcet, J.T., ed., Population and Environment.

Dorigo, T.(1983), "“"Push-Pull Migration Laws", Annals Assn. Am. Geographers, 73 (1) 1-17.

Keenan, J.G. (1981), "Irish Migration: All or Nothing Resolved?", Economic and Social Review, 12, 169-186.

Farrell N. (February 1991), "Emigration - the Galway Experience." Galway Action on Poverty Report. (GAPR) Galway.

Fidrmuc, J. (2002), "Migration and Regional Adjustment to Asymmetric Shocks in Transition Economies". CPB Discussion Paper No. 007. 
Geary, P., O'Grada, C. (1989), "Postwar Migration between Ireland and the UK” in "European Mobility: Trends and Consequences," in Gordon, I., Thirwall, A. P. eds.,

Harris, J.R., Todaro, M. P. (1970) "Migration, Unemployment and Development: A Two Sector Analysis." American Economic Review, 60 (1), 120-142.

Hazelkorn, E. (1990), "British Labour and Irish Capital." Galway Labour History Publication, The Emigrant Experience, Galway.

Mac Laughlin, J. (1994), "Ireland: The Emigrant Nursery and the World Economy", Cork University Press.

Sexton, J. J., Walsh, B. M., Hannan, D. F., McMahon, D. (1991), "The Economic and Social Implications of Emigration." Dublin, National Economic and Social Council.

Ravenstein (1885), "The Laws of Migration." Journal of the Statistical Society of London, 48 (2), pp. 167-235.

(1876), "The Birthplace of the People and the Laws of Migration." The Geographical Magazine, Vol. 3, pp. 173-177, 201-206, 229-233. (1889), "The Laws of Migration." Journal of the Royal Statistical Society, 52 (2)., pp. 241 -

305.

Todaro, M. P. (1969), "A Model of Labor Migration and Urban Unemployment in Less Developed Countries." American Economic Review 59 (1), 138-148.

Vavrejnová, M. (2004), "Mobilita pracovní síly před a po vstupu ČR do EU.” Praha, CERGE.

VÚPSV (2001), "Důsledky vstupu ČR do EU na vztahy s Rakouskem se zaměřením na zaměstnanost, trh práce a migraci." závěrečná zpráva, Praha.

Walsh, B. M. (1974), "Expectations, Information, and Human Migration: Specifying an Econometric Model of Irish Migration to Britain", Journal of Regional Science, 14, 107-120.

(1987), "The Impact of Demographic Variables on Unemployment in "The Challenge of Unemployment." Administration, vol. 35 (3), Dublin.

Dublin. (1987), "Why is Unemployment so High in Ireland?" Centre for Economic research, UCD, (1989), "Testing for the Existence of Macroeconomic Feedback from Large-Scale Migration.". The Economic adn Social Review, Dublin.

Statistics and National Statistics: Austrian Statistical Office: (www.statistik.at), Irish Central Statistical Office (www.cso.ie), Irish Ministry of Agriculture (www.agriculture.gov.ie), Czech Statistical Office (www.czso.cz), German Statistical Office (www.destatis.de) 